\title{
Breeding biology of the Little Cormorant Phalacrocorax niger (Pelecaniformes: Phlacrocoracidae) in Bangladesh
}

\author{
Habibon Naher ${ }^{1}$, Noor Jahan Sarker ${ }^{2}$, Md. Khalilur Rahman ${ }^{3}$ \& Shawkat Imam Khan ${ }^{4}$ \\ 'Lecturer (Biology), Shahid Zia Girls' College, Jatrabari, Dhaka 1204, Bangladesh \\ ${ }^{2,3}$ Professor, Department of Zoology, University of Dhaka, Dhaka 1000, Bangladesh \\ ${ }^{4}$ Taxidermist, Department of Natural History, Bangladesh National Museum, Shahbag, Dhaka 1000, Bangladesh \\ Email: ${ }^{4}$ sukhi_194@yahoo.com (corresponding author)
}

Date of online publication 26 April 2009 ISSN 0974-7907 (online) | 0974-7893 (print)

Editor: Rajah Jayapal

Manuscript details:
Ms \# 01790
Received 27 May 2007
Final received 14 March 2009
Finally accepted 25 March 2009

Citation: Naher, H., N.J. Sarker, M.K. Rahman \& S.I. Khan (2009). Breeding biology of the Little Cormorant Phalacrocorax niger (Pelecaniformes: Phalacrocoracidae) in Bangladesh. Journal of Threatened Taxa 1(4): $221-225$

Copyright: (c) Habibon Naher, Noor Jahan Sarker, Md. Khalilur Rahman \& Shawkat Imam Khan 2009. Creative Commons Attribution 3.0 Unported License. JoTT allows unrestricted use of this article in any medium for nonprofit purposes, reproduction and distribution by providing adequate credit to the authors and the source of publication.

Author Details: HABIBON NAHER has been working as Lecturer of Biology for the last six years. Currently, she has registered for a $\mathrm{PhD}$ on Kingfishers of Bangladesh. She has already published several scientific papers on different aspects of wildlife of Bangladesh in different national and international journals.

NOOR JAHAN SARKER is the Chairman of the Department of Zoology. She has published nearly 70 research papers dealing with different aspects of Bangladesh's wildlife in national and international journals and more than 100 popular scientific articles and four books.

MD. Khalilur Rahman is a Professor of Zoology and has been doing several research works on wildlife and environmental issues in Bangladesh. He specializes in Ornithology. SHAWKAT IMAM KHAN is involved in wildlife research in Bangladesh for the last seven years. Currently, he works as a taxidermist.

Author contribution: All of the authors have equal contribution to do the study and preparation of the manuscript.

Acknowledgements: The authors are especially grateful to Mr. Tauhid Uddin Ahmed, Ex-Principal Scientific Officer, IECDR, Mohakhali, Dhaka, Bangladesh for making helpful and constructive comments to enrich this paper.

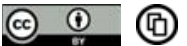

OPEN AGCESS | FREE DOWNLOAD
Abstract: The breeding biology of the Little Cormorant Phalacrocorax niger was studied in a nesting colony at Dhonagoda Village in Chandpur District, Bangladesh between 2003 and 2005. The breeding activities of the Little Cormorant commenced in May and continued till October. The major nesting trees of the colony included Albizzia procera, Mangifera indica, Ficus spp., Streblus asper and Cocos nucifera. Both partners took part in nest building $(n=33)$. The nest building period was 8 to 15 days (mean $\pm S D$ $10.85 \pm 1.98)$ and the clutch size $(n=20)$ varied from 2 to $6(3.75 \pm 0.8)$. The length and diameter of the eggs $(n=115)$ ranged between 4.05 and $4.98 \mathrm{~cm}(4.5 \pm 0.18)$ and 2.5 and $3.03 \mathrm{~cm}(3 \pm 0.07)$ respectively. The eggs weighed between $14 \mathrm{~g}$ and $25 \mathrm{~g}(18.4 \pm 0.88)$. The incubation period was from 14 to 21 days $(17.3 \pm 2.1)$ and the weight of the hatchling varied from $4 \mathrm{~g}$ to $18.2 \mathrm{~g}(10.45 \pm 3.6)$. The brooding period was from 15 to 20 days (17.3 \pm 1.26$)$. The young flew away from the nest at the age of 17 to 29 days $(20.85 \pm 2.8)$ after hatching when the weight was $350 \mathrm{~g}$ to $470 \mathrm{~g}(411.93 \pm 28.55)$. The breeding success was $78.76 \%$ in relation to eggs hatched and $68.26 \%$ in relation to eggs laid.

Keywords: Bangladesh, breeding season, clutch size, hatching success, incubation, nesting material, mortality rate, Phalacrocorax niger.

\section{INTRODUCTION}

Although the natural history of Little Cormorant Phalacrocorax niger is well known through a large number of anecdotal reports (Jerdon 1862; Whistler 1949; Wallace 1971; Ali 1977, Barnes 1981; Welty \& Baptista 1988; Perrins 1990), very few research works on the breeding biology of the species exist (Sirriwannichkul 1981). For scientific management of the cormorant population and their conservation, it is imperative to study breeding ecology, survival, and mortality and factors that influence their breeding success. Though cormorants, as a group, are well-studied, Little Cormorant has received scant attention from bird biologists. In particular, there exists no published information on the breeding biology of Little Cormorant in Bangladesh. In an attempt to fill this information gap, this study was conducted to understand the breeding biology of the Little Cormorant with emphasis on biometry of eggs and fledgling success in Bangladesh.

\section{Material and Methods}

The study was conducted in a nesting colony at Dhonagoda Village near Dhonagoda River under the Upazila Matlab (North) in the district of Chandpur, Bangladesh. The colony was situated at the northern side of Dhonagoda Bazar, eastern side of MatlabDhonagoda embankment and western side of Dhonagoda river, a place $47.5 \mathrm{~km}$ southeast away from the capital city of Dhaka. The geographical position of the area is $23^{\circ} 28.334{ }^{\prime} \mathrm{N}$ \& $90^{\circ} 41.610^{\prime} \mathrm{E}$.

The study area has typical tropical climate with May being the hottest (average $30.3^{\circ} \mathrm{C}$ ) and January the coldest (average $17.2^{\circ} \mathrm{C}$ ) month. Temperature ranges from $12.2^{\circ} \mathrm{C}$ to $34.4^{\circ} \mathrm{C}$ (average $26.18^{\circ} \mathrm{C}$ ). The mean annual rainfall was $173.75 \mathrm{~mm}$ with a maximum of $754 \mathrm{~mm}$.

The total area of the colony site was $20305.13 \mathrm{~m}^{2}$. The colony was located at the vicinity of two ponds. There was a passage in between the ponds, which was being used as access path to the embankments. The Matlab-Dhonagoda road passes along the embankment. The area of the pond of the western side of the passage was $14179.06 \mathrm{~m}^{2}$ and another one was $8562.93 \mathrm{~m}^{2}$. The $\mathrm{pH}$ level of the water of one pond was 8.9 and the other was 7.4. The water depth was $1.2 \mathrm{~m}$ at the early breeding season (March-April) and 3-3.6 m during monsoon.

We used pan-balance (graduated between 0-2000g), spring balance (5-1000g), slide calipers, steel scale (graduated up to $1 \mathrm{~mm})$, tape scale $(1-150 \mathrm{~cm})$, meter tape $(1 \mathrm{~cm}-50 \mathrm{~m})$, manual counter, pH meter, and GPS (12XL, Garmin) during the study period. The area 
was visited twice a week during breeding season and once a week during non-breeding season.

Windows spreadsheet program Excel and statistical software SPSS (version 12) were used to do all the computations and numerical analyses. All the mean values are provided with standard deviations.

\section{Results and Discussion}

\section{Breeding season}

The breeding of the Little Cormorant began in May and continued until October, similar to observations by Whistler (1949), Smythies (1953), Ali \& Ripley (1968), Begum (1977), and Siriwannichkul (1981). The slight variations in the above studies are to do with changes in the rainy seasons between southern India, Sri Lanka and Thailand.

The peak month in nesting was observed between July and August in the present observation but it was February through July in Kerala, a southwestern state of India (Jayson 2001). Again, these differences of nesting months can be explained with the advent of rainy season, which is different in different places.

\section{Morphological changes of the bird during breeding season}

The colour of the feathers becomes dull at the early breeding season (May-June) with a short occipital crest in both the sexes. Occurrence of Little Cormorant with white and brown feathers was reported by Ripley (1962) \& Jayson (2001). Thomson (1965) mentioned the ornamental patches in orbital skin and chin. In both sexes the whole margin of the gular pouch was observed to become paler during breeding period. Jerdon (1862) \& Whistler (1949) observed that the gular pouch was livid. But Thomson (1965) found colourful patches on the gular pouch of the bird. In the present study, black bristle like plumes on either side of the beak and white eyelashes were found on the body of the birds. Some workers found livid eyelids during the breeding period of the birds (Jerdon 1862; Whistler 1949). Jerdon (1862) in his observation also found a white triangular spot on the head of the bird.

\section{Breeding Colony}

During the study period the Little Cormorant built their nests $(\mathrm{n}=294)$ with the Indian Pond Heron Ardeola grayii $(\mathrm{n}=37$ constituting $11.11 \%$,) and the Little Egret Egretta garzetta (n=2 forming $0.60 \%$,). The Little Cormorant breeds on trees in company with darter and egrets (Smythies 1953). Ali \& Futehally (1967) mentioned that the cormorants frequently built their nests in mixed colonies with egrets and storks. Begum (1997) reported that the Little Cormorant built their nests in mixed colonies with Intermediate Egret and Flying Fox.

\section{Selection of nest site}

From the study it was found that, the cormorants built their nests on tress close to human habitation, however, always near to water body. It is seen that cormorants build nests on trees close to water bodies (Whistler 1949, Ali \& Futehally 1967, Siriwannichkul 1981; Begum 1997); in rare occasions nesting trees are also found away from water bodies (Ali 1977).

\section{Nesting trees}

The Little Cormorant has been observed to nest on Albizzia procera (5.48\%), Mangifera indica (61.07\%), Ficus spp. (24.5\%), Streblus asper (6.85\%) and Cocos nucifera (2.1\%). It bred only on trees (Jerdon 1862; Ali 1977). However, in India it occasionally bred in reed-beds (Whistler 1949). Smythies (1953) described that in Burma they bred in bamboo and palms as well as in trees. The height and GBH (girth at breast height) of the nesting trees ranged from $9.2 \mathrm{~m}$ to $11.2 \mathrm{~m}(10 \pm 0.76 \mathrm{~m})$ and $66 \mathrm{~cm}$ to $125 \mathrm{~cm}(96 \pm 20.97 \mathrm{~cm})$ respectively. The maximum height of nests ranged from $7.8 \mathrm{~m}$ to $10.6 \mathrm{~m}(9.4 \pm 0.8)$ from the ground and the minimum height was $6 \mathrm{~m}$ to $10.2 \mathrm{~m}(8.5 \pm 1.25 \mathrm{~m})$. Begum (1997) reported that they built their nests between $13.5 \mathrm{~m}$ to $17.5 \mathrm{~m}$ height above the ground.

\section{Nesting materials}

Major plant species used for collecting nesting material by Little Cormorants include Capsicum frutescens, Eucalyptus citriodora, Coriandrum sativum, Cynodon dactylon, Enhydra fluctuans, Corchorus olitorius, Ziziphus jujuba, Mangifera indica and Polygonum sp (Table 1). Twigs used in nest building were observed by Ali \& Futehally (1967). Sticks used in the nest construction were observed by several authors (Lewis 1929; Kortlandt 1938, 1940; Whistler 1949; Smythies 1953; Ali 1977; Barnes 1981). Thomson (1965) mentioned sea-weeds, vegetation of sticks as nesting material depending on the site. Caesalpinia pulcherrima were used in captivity as nesting material (Sarker \& Naher 2007).

\section{Measurement of the nests}

The nest was a cup shaped structure with a depression in the middle. The maximum height of the nests varied from $7.8 \mathrm{~m}$ to $10.6 \mathrm{~m}(9.4 \pm 0.8)$ from the ground.

The outer diameter of the nests $(n=20)$ varied from 19 to $45 \mathrm{~cm}(27.15 \pm 5.8)$ while the inner diameter of the cup ranged from 9 to $20 \mathrm{~cm}(14.3 \pm 2.8)$. The depth of the cup was from 4 to $8 \mathrm{~cm}(5.4 \pm 1.4)$.

\section{Nest building}

Both of the partners took part of the collection of the nest material and the arranging of the material, that used their breast, legs and bill to give the nest a proper shape. The observed participation of both the sexes of Little Cormorant in nest-building was also mentioned in Ali \& Ripley (1968).

The Little Cormorant took 8 to 15 days $(10.85 \pm 1.98$ days) $(\mathrm{n}=20)$ for nest building. Begum (1997) reported that they took 4 to 6 days (average 4.9 days).

\section{Egg laying}

It was observed that most of the eggs were laid at one-day interval. Begum (1997) also had similar observation in a study in Tangail district of Bangladesh. But a few eggs (10\%) were also laid at an interval of two days in our study. Interestingly, two eggs were laid on the same day in one instance, one in the morning and the other in the evening.

\section{Clutch size}

The clutch size of the Little Cormorant varied from 2 to 6 $(3.75 \pm 0.8)(n=20)$ as observed during the present study. The clutch size has been observed to range from 2 to 5 sometimes 7 (Jerdon 1862; Whistler 1949; Thomson 1965; Ali \& Ripley 1968; Ali 1977; Siriwannichkul 1981; Barnes 1981; Begum 1997). 
Table 1. Material used in nest construction

\begin{tabular}{lll}
\hline Major plant species & $\begin{array}{l}\text { Part used as } \\
\text { nesting material }\end{array}$ & Frequency of use (\%) \\
\hline Capsicum frutescens & Dry twigs & 25.5 \\
Eucalyptus citriodora & Leaves & 1 \\
Coriandrum sativum & Dry fruit & 0.5 \\
Cynodon dactylon & Dry plant & 40 \\
Ziziphus jujuba & Stem & 1 \\
Polygonum sp. & Twigs & 9 \\
Enhydra fluctuans & Dry plant & 1 \\
Corchorus olitorius & Dry fiber & 5 \\
Mangifera indica & Stem & 17 \\
\hline
\end{tabular}

Table 2. Correlation and co-efficient in different parameters of eggs measurements $(n=30)$.

\begin{tabular}{lllll}
\hline Areas & Parameters & $\begin{array}{l}\text { Correlation } \\
\text { Coefficient }(\mathbf{r})\end{array}$ & $\begin{array}{l}\text { Statistical } \\
\text { interference }\end{array}$ & $\mathbf{p}$ \\
\hline In Nature & Egg length \& girth & -0.008 & Significant & 0.01 \\
& Egg length \& weight & 0.323 & Significant & 0.01 \\
& Egg girth \& weight & 0.311 & Significant & 0.05 \\
\hline
\end{tabular}

\section{Shape of the eggs}

The shape of the eggs was oval, more or less pointed at one end and the other end was round in concurrence with the observation of Barnes (1981).

\section{Colour of the eggs}

The newly laid egg was white to bluish-white. Jerdon (1862) mentioned that the eggs were pale green in colour. Barnes (1981) \& Begum (1997) mentioned that the eggs were white or bluish-white in colour when freshly laid. Ali (1977) described that the colour was pale bluish-green with a chalky surface.

In the present study, it was observed that the eggs were becoming brownish or yellowish as incubation proceeded (Image 1). Such soiling of egg-shells with time has been reported in Little Cormorants before as well (Whistler 1949; Barnes 1981). Wallace (1971), however, described that the egg colour may change strikingly with age beyond the mere tarnishing that goes with continued incubation.

\section{Measurement of the eggs}

The length of the eggs ranged from $4.05 \mathrm{~cm}$ to $4.98 \mathrm{~cm}$ $(\mathrm{n}=115)($ mean $4.5 \pm 0.18 \mathrm{~cm})$. The average diameter of egg was $3 \pm 0.07 \mathrm{~cm}(\mathrm{n}=115)$ with a variation of 2.5 to $3.05 \mathrm{~cm}$. The weight of the eggs varied from $14 \mathrm{~g}$ to $25 \mathrm{~g}(\mathrm{n}=115)$ (mean $18.4 \pm 088 \mathrm{~g})$.

The mean dimension was $4.5 \times 3 \mathrm{~cm}(1.77 \times 1.14 \mathrm{in})$ and Whistler (1949) reported it was $1.75 \times 1.15 \mathrm{in}$. The average size was 4.48 x $2.9 \mathrm{~cm}$ (Ali \& Ripley 1968). Begum (1997) described that the average size of $38 \mathrm{eggs}$ to be $4.4 \times 2.8 \mathrm{~cm}$.

From the statistical analyses it was revealed that the length was positively correlated with weight and girth and the tests were statistically significant (Table 1).

\section{Incubation}

The female started incubating immediately after laying the first egg. This was also reported by Ali \& Ripley (1968) and Begum (1997). Both the sexes are said to take equal part in incubation (Ali \& Ripley 1968).

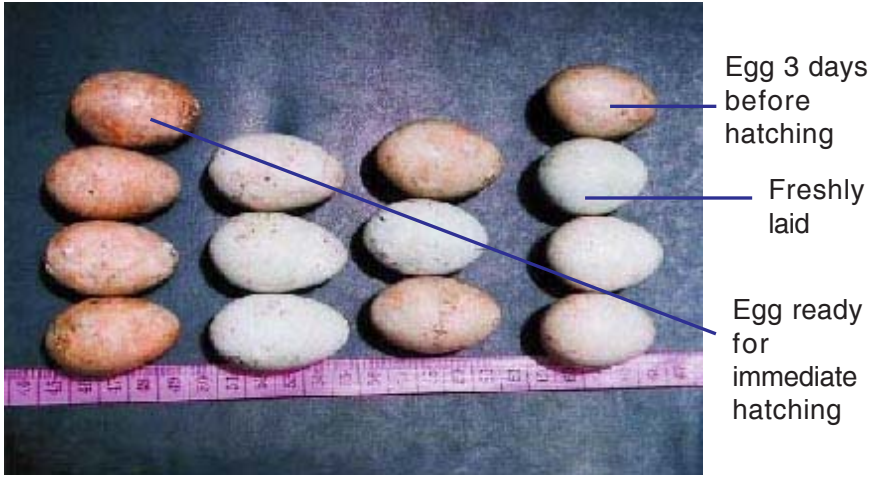

Image 1. Colour of the eggs

\section{The incubation period}

The incubation period varied from 14 to 21 days (mean 17.3 $\pm 2.1)$ and it increased significantly with the clutch size $(r=$ $0.671, \mathrm{n}=20, \mathrm{p}<0.05)$. The length of the incubation period was marginally lower in the present study in comparison with the published observations elsewhere, which was 22-26 days (Siriwannichkul 1981; Perrins 1990; Begum 1997).

\section{Egg mortality}

We observed clutch loss to the tune of $13.74 \%$ in the Little Cormorants in the current study. Earlier, Begum (1997) reported $36.82 \%$ egg mortality. Stealing (by the local boys for consumption) was the main cause of the egg loss in the present study (Fig. 1). Other causes that have been attributed to loss include predation (10.52\%), human interference $(7.89 \%)$, infertility $(5.26 \%)$, handling $(5.26 \%)$ and sudden fall $(2.63 \%)$ (Begum 1997).

\section{Weight variation of eggs}

The weight of the egg varied significantly during incubation period. During first 10 days of incubation, the weight increased, by $3.11 \%$ of the original measure. However, egg weight decreased afterwards drastically by $38.86 \%$ of the original weight. The weight loss of the eggs varied from 8 to $10 \mathrm{~g}$ in the present study (Fig. 2) in sharp contrast to earlier studies, which recorded the loss in the range of 1 to $4 \mathrm{~g}$ (Begum 1997).

\section{Hatching success}

The eggs hatched during daytime, with a crack of the eggshell at the middle of the egg in an interval of 1 to 3 days $(n=20)$. The egg was broken at transverse section with the help of the egg tooth. The hatching success was $86.26 \%$ in the present study, while in a previous study it was $63.15 \%$ (Begum 1997). Elsewhere it was reported to be $80 \%$ (Kopciewicz et al. 1999).

\section{Brooding}

After the first of the eggs hatched, the female started to brood. Both the mates took turns to brood. Brooding continued until the development of primaries and secondaries. When the feathers developed densely ( $7^{\text {th }}$ to $10^{\text {th }}$ day), the brooding was discontinued. From the first day of hatching to the seventh day, the skin of the hatchling was naked and this was the time when continuous brooding was observed. At night the female brooded continuously and the male sat on the branch beside the 


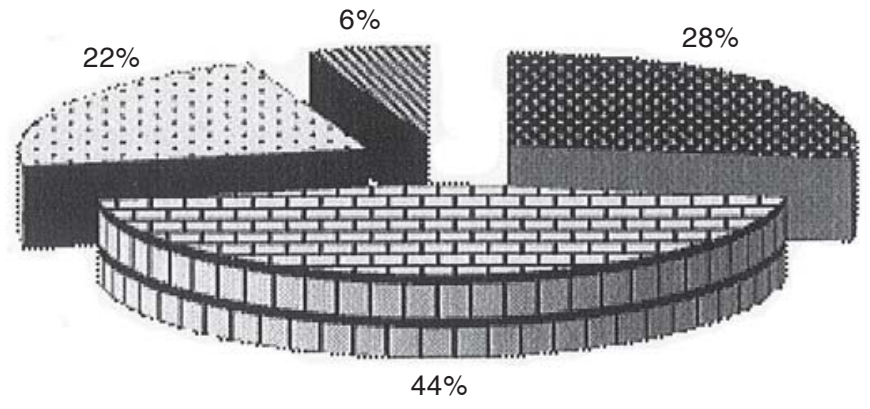

Infertility 도 Stolen Unknown causes $\mathbf{\mathbb { N }}$ Experimental study

Figure 1. Loss of eggs

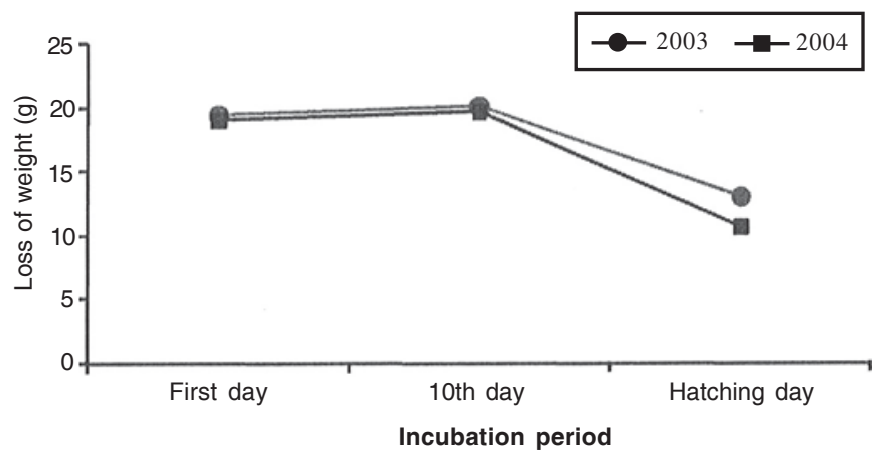

Figure 2. Loss and gain of weight of eggs

nest. The brooding period varied from 15 to 20 days (17.3 \pm $1.26)$.

\section{Opening of the eyes}

During hatching, the eyes of the hatchlings were closed, opening gradually as time progressed and as they grew. They opened their eyes completely when the chicks were 8 to 12 days old (9.8 \pm 0.95 days). From the data it was found that the eyes of the comparatively healthier nestlings opened first than the low weight nestlings and this difference was found to be statistically significant $(\mathrm{t}=26.762, \mathrm{df}=19, \mathrm{p}<0.01)$. Palmer $(1962)$ described that eyes opened between 4 to 5 days of age in case of Large Cormorant. At the time of the opening of the eyes the weight of the nestlings varied from $132 \mathrm{~g}$ to $240 \mathrm{~g}$ (197.6 \pm 31.81 ) in the present study. Begum (1997) reported that it was 40 to $89 \mathrm{~g}$

\section{Disappearing of the egg tooth}

The egg tooth disappeared when the chicks were 12 to 17 days old (mean 14.4 \pm 1.4 day). Begum (1997) mentioned that the nestlings took 15 to 25 (mean 18.68) days to shed their egg teeth. At that time the weight varied from $220 \mathrm{~g}$ to $365 \mathrm{~g}$ in the present study whereas Begum (1997) reported that the average weight was $224.6 \mathrm{~g}$.

\section{Development of feathers}

Little Cormorant are nidicolous species and as such, the body was transparent and naked at the first day of hatching. Within 7 to 10 days the primaries of the wing and the rectrices of the tail feathers started to develop. The fine down feathers were also observed emerging on the lower belly. Begum (1997) reported that the blackish pre-pennae of fine down feathers
Stolen $\mathbf{0}$ Natural death $\square$ Sudden fall during experiment

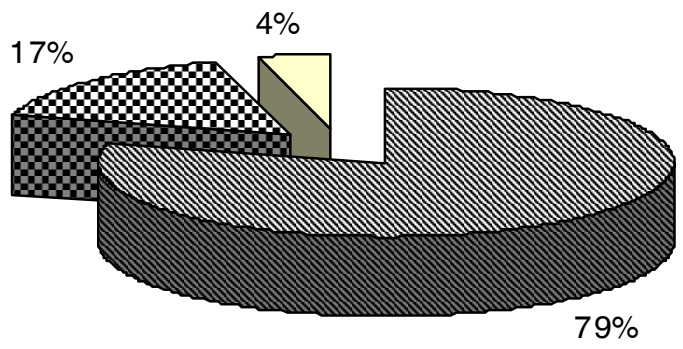

Figure 3. Loss of nestlings

became visible on the wings and the pectoral region from the first day up to seven days of age. By days 12 and 13 the whole body was covered by down feathers except the head.

\section{Fledging period}

The juvenile birds left the nest between 17 to 29 days $(20.85 \pm 2.8)(\mathrm{n}=20)$ after hatching. The fledging time was not positively correlated with the weight of the fledgling $(r=0.219$, $\mathrm{df}=18, \mathrm{t}=76.231, \mathrm{p}>0.05$ ). According to Siriwannichkul (1981) the young fledged in 35 to 42 days. Begum (1997) reported it to be 39 to 45 days (mean 41.04 days).

During the fledging time the weight varied from $350 \mathrm{~g}$ to $470 \mathrm{~g}(\mathrm{n}=20)$, whereas the weight ranged between $400 \mathrm{~g}$ to $445 \mathrm{~g}$ in a similar study (Begum 1997).

\section{Nestling mortality}

In the study period, $23.3 \%$ nestlings failed to fledge. The main cause of loss was that $18.45 \%$ were stolen by the local boys (Fig. 3). In another study, Begum (1997) reported predation by other birds $(12.5 \%)$ and loss due to natural causes (12.5\%). Jayson (2001) reported that House Crow was the main predator of the eggs and nestlings of many species including the Little Cormorant. He also stated that the common Rat Snake (Ptyas mucosus) was a potential threat to eggs and nestlings. Fortunately, the House Crow was not seen in the area during the study period. During heavy rain, many nestlings fell down and were easy prey to the ground predators (Subramanya \& Moni 1996; Jayson 2001). Kopciewicz et al. (1999) observed that very strong winds may cause considerable increase in egg and chick mortality.

\section{Conclusion}

The result of the study has some quite interesting information on breeding, as well as major threats to nest, egg, and survival of chick of the Little Cormorant. Human disturbance and habitat destruction was the main causes for decreasing the population. So, public awareness should take the major role for the conservation of the Little Cormorant.

\section{References}

Ali, S. (1977). The Book of Indian Birds (10 ${ }^{\text {th }}$ edition). Bombay Natural History Society, Bombay, xvii+175pp.

Ali, S. \& L. Futehally (1967). Common Birds. National Book Trust, New Delhi, ix $+117 p p$. 
Ali, S. \& S.D. Ripley (1968). Compact Handbook of the Birds of India and Pakistan Vol. 1. Oxford University Press, Bombay, viii+380pp.

Barnes, H.E. (1981). The Birds of India (A guide to Indian ornithology). Vol. 2 Cosmo Publications, New Delhi, xiii+737pp.

Begum, A.R. (1997). The breeding biology and daily activities of little cormorant, Phalacrocorax niger (Vieillot). M.Sc. Thesis. Dept. of Zoology, University of Dhaka, Dhaka. Pp. xi+121 (unpublished).

Jayson, E.A. (2001). Status, composition and conservation of birds in Mangalavanam Mangroves, Cochin, India. Zoos' Print Journal 16(5): $471-478$.

Jerdon, T.C. (1862). The Birds of India. Vol. 11, part 1. The Military Orphan Press, Calcatta, xiv +535pp.

Kopciewicz, P., C. Nitecki, S. Bzoma \& L. Stempniewicz (1999). Breeding success of cormorants Phalacrocorax carbo sinensis in the colony at Katy Rybackie ( N Poland). 23rd Annual Meeting and Workshops 812 November 1999, Palazzo Congressi, Grasdo, Italy. Waterbird Conservation and Management.

http://web.tiscali.it/sv2001/cormo_abstract/sunti_cwgrado.htm

Kortlandt, A. (1938). De uitdrukkingsbewegingen en-geluiden van Phalacrocorax carbo sinensis (Shaw \& Nodder). Ardea 27: 1-40.

Kortlandt, A. (1940). Eine Übersicht der angeborenen Verhaltungsweisen des Mittel-Europäischen Kormorans (Phalacrocorax carbo sinensis [Shaw \& Nodd.]), ihre Funktion, ontogenetische Entwicklung und phylogenetische Herkunft. Extrait des Archives de Néerlandaises Zoölogie 4: $401-442$.

Lewis, H.F. (1929). The Natural History of the Double-crested Cormorant (Phalacrocorax auritus auritus Lesson). Ru-Mi-Lou Books, Ottawa, 94pp.

Palmer, R.S. (ed.) (1962). Handbook of North American Birds. Vol. I. Yale University Press, New Haven, 567pp.
Perrins, C.M. (1990). The Illustrated Encyclopedia of Birds: The Definitive Guide to Birds of The World. International Council for Bird Preservation, Marshall editions developments Ltd. Great Britain, 420pp.

Ripley, S.D. (1962). Unusual plumage of the Little cormorant, Phalacrocorax niger (Vieillot). Journal of Bombay Natural History Society 59: 285-286.

Sarker, N.J. \& H. Naher (2007). Nest and Nest building behaviour of the Little Cormorant (Phalacrocorax niger) in Bangladesh Journal of Zoology 35(2): 269-274.

Siriwannichkul, O. (1981). Food Habits and Breeding Biology of Little Cormorant (Phalacrocorax niger). Kasetsart Univ. Bangkok. Thailand, $68 \mathrm{pp}$

Smythies, B.E. (1953). The Birds of Burma. $2^{\text {nd }}$ edition. Oliver and Boyd, Edinburgh, xxxix+668pp.

Subramanya, S. \& K. Moni (1996). Saving the Spot-billed Pelican. A successful experiment. Hornbill 2: 2-6.

Thomson, A.L. (1965). A New Dictionary of Birds. Thomas Nelson and Sons, London. 928pp.

Wallace, G.J. (1971). An Introduction to Ornithology. $2^{\text {nd }}$ edition. The Macmillan Company. Collier-Macmillan Limited, London, xiii+491pp.

Welty, J.C. \& L. Baptista (1988). The Life of Birds. Saunder College Publishing, New York, $\mathrm{x}+546 \mathrm{pp}$.

Whistler, H. (1949). Popular Handbook of Indian Birds. $4^{\text {th }}$ edition. Gurney and Jackson, London, xxiv+438pp. 